\title{
Model Penyaluran Zakat Sebagai Instrumen Keuangan Sosial untuk mencapai Maqashid Syariah dengan menggunakan Pendekatan Analytic Network Process
}

\author{
Syawal Harianto ${ }^{1 *}$, Marliyah ${ }^{2}$, Fuadi $^{3}$, Haris Al Amin ${ }^{4}$ \\ 1,4 Dosen Politeknik Negeri Lhokseumawe, Provinsi Aceh, Indonesia. \\ 2 Universitas Islam Negeri Sumatera Utara, Provinsi Sumatera Utara, Indonesia. \\ ${ }^{3}$ Dosen Universitas Malikussaleh, Provinsi Aceh, Indonesia.
}

\begin{abstract}
Abstrak. Islam menuntut zakat untuk kesejabteraan umat Islam. Zakat adalah keempat dari rukun Islam. Kontribusi zakat dan maqashid syariah memiliki bubungan langsung. Penelitian ini bertujuan untuk. mengetabui relevansi kontribusi zakat dalam mencapai maqashid syariah dengan metode ANP. Metode ANP digunakan untuk. menyelesaikan masalah dalam penguraian sintesis dan skala kriteria. Penelitian ini menggunakan teknik purposive sampling. Responden penelitian ini abli dan berpengetabuan luas di bidang ini (zakat). Hasil penelitian ini menunjukkan peringkat masing-masing kriteria dari senif sumbangan zakat. Kriteria senif fakir adalah tidak ada apa-apa. Kriteria senif miskin adalah orang yang memiliki uang kurang dari nisab. Kriteria senif amil adalah mukallaf. Kriteria senif muallaf adalah orang baru dalam agama islam. Kriteria senif gharimin adalah hutang seumur hidupnya. Kriteria Senif fisabilillah ditetapkan sebagai pusat dakwah. Kriteria Senif Ibnu sabil adalah musafir bagi kesejabteraan. Prioritas maqashid syariah dalam senif sumbangan zakat adalah agama, kemudian prioritas sumbangan zakat untuk mencapai maqasid syariah adalab fakir. Sumbangan zakat harus disalurkan lebih baik lagi untuk kesejabteraan umat Islam.
\end{abstract}

Kata kunci: Analytic Network Process (ANP); Kontribusi Zakat; Maqashid Syariah.

Abstract. Islam requerer tompay zakat for wellbeing of Islamic people. Zakat is the forth of Islamic pillars. The contribution of zakat and maqashid syariah has the direct relations. This study aimed to know the relevale of zakat's contribution to reach maqashid syariah with ANP method. ANP method is used to completed the problem in decomposition of synthesis and criterion scale. The study I s used techniques purposive sampling. Responden the study is expert and knowledgeable in this field (zakat). The result of this study showed the rank of each criterion from senif contribution of zakat. Senif fakir criterion is that have'nt anything. Senif miskin criterion is people that have the money less than the nisab. Senif amil criterion is mukallaf. Senif muallaf criterion is the new people in Islam religion. Senif gharimin criterion is the owed for his life. Senif fisabilillah criterion is established the dakwah center. Senif Ibnu sabil criterion is musafir for wealfare. The priority of maqashid syariab in senif contribution of zakat is religions. Then the priority contribution of zakat to reach maqasid syariah is fakir. The contribution of zakat should be distributed better for the welfare of muslims.

Keywords: Analytic Network Process (ANP); Contribution of Zakat; Maqashid Syariah. 


\section{Pendahuluan}

Agama Islam merupakan agama yang memberikan rahmat bagi seluruh alam, dengan memberikan tuntunan dan pedoman bagi seluruh manusia. Islam menjadi ajaran untuk memahami petunjuk dari Allah SWTT yang telah menciptakan alam semesta dan segala isinya. Sehingga manusia dapat menyeimbangkan persoalan duniawi dan persoalan akhirat di dalam kehidupannya, tanpa harus memberikan perbedaan prioritas diantara keduanya.

Dalam bidang ekonomi Islam tidak memposisikan aspek duniawi sebagai tujuan utama dari aktivitas kehidupan manusia didalam perekonomian, hal ini karena Islam memposisikan aktivitas ekonomi sebagai sebuah kegiatan atau aktivitas yang dapat menghadirkan kesejahteraan didalam kehidupan. Untuk mencapai kesejahteraan umat manusia, khususnya umat Islam. Maka, Islam memberikan kewajiban dan anjuran untuk membayar Zakat, Infak, Sedekah dan Wakaf (ZISWAF).

Zakat merupakan salah satu rukun Islam yang yang keempat, dalam hal ini berarti bahwa zakat termasuk dalam instrumen wajib untuk umat muslim dalam pengabdian kepada Allah SWT yang memberikan manfaat baik pada bidang ekonomi maupun pada bidang sosial. Orang yang berhak menerima zakat disebut dengan mustahiq, yang berjumlah delapan ashnaf atau golongan.

Dalam Al-Qur'an surat at-Taubah (9:60), menjelaskan bahwa terdapat delapan ashnaf (mustabiq) yaitu fakir, miskin, riqab (hamba sahaya), ibnu sabil (musafir), amil, muallaf, dan orang yang berhutang demi tujuan yang baik dan orang yang berjuang di jalan Allah SWT .

Penyaluran zakat untuk mustahiq di realisasikan ke dalam program-program sosial, ekonomi, pemberdayaan, dan program yang lainnya. Pada Baitul Mal Kota Lhokseumawe, dana zakat yang terkumpul disalurkan untuk bantuan sosial yang dilaksanakan dalam dua tahap oleh Sekretariat Baitul Mal Kota Lhokseumawe. Bantuan soaial tersebut diberikan untuk tujuh senif yang terdiri dari fakir, miskin, amil, muallaf, gharimin, fisabilillah dan ibnu sabil.
Kontribusi zakat terdiri atas kontribusi penerimaan dan kontribusi penyaluran. Jumlah dari kontribusi tersebut pada Tabel 1 berikut ini:

Tabel 1. Penerimaan dan Penyaluran Dana Zakat, Infak, Sedekah (ZIS) Pada Baitul Mal Kota Lhokseumawe.

\begin{tabular}{ccc}
\hline Tahun & $\begin{array}{c}\text { Pemasukan ZIS } \\
(\mathbf{R p})\end{array}$ & $\begin{array}{c}\text { Penyaluran ZIS } \\
(\mathbf{R p})\end{array}$ \\
\hline 2015 & 7.547 .270 .363 & 2.971 .002 .588 \\
2016 & 4.700 .000 .000 & 3.334 .800 .000 \\
2017 & 7.621 .400 .919 & 5.763 .606 .700 \\
2018 & 9.790 .038 .935 & 5.644 .751 .210 \\
2019 & 7.160 .743 .175 & 4.193 .150 .000 \\
$\sum$ & 36.819 .453 .392 & 21.907 .310 .498 \\
$\%$ & $\mathbf{1 0 0} \%$ & $\mathbf{5 9 , 4 9 \%}$ \\
\hline
\end{tabular}

Sumber: Laporan Keuangan Baitul Mal Kota Lhokseumawe

Realisasi dari jumlah bantuan sosial belanja zakat pada sekretariat Baitul Mal Kota Lhokseumawe tahun anggaran 2019 yang dilaksanakan pada tahap I dan II ke dalam tujuh senif. Realisasi belanja zakat pada sekretariat Baitul Mal Kota Lhokseumawe pada tahap I dan II dapat dilihat dalam tabel 2 berikut ini:

Tabel 2. Penyaluran Bantuan Sosial Belanja Zakat Pada Sekretariat Baitul Mal Kota Lhokseumawe Tahun Anggaran 2017 Tahap I dan II.

\begin{tabular}{llrrrr}
\hline \multicolumn{1}{c}{ Senif } & $\sum$ & $\begin{array}{c}\text { Realisasi } \\
\text { (jutaan) }\end{array}$ & $\begin{array}{c}\text { Realisasi } \\
\text { (jutaan) }\end{array}$ & \% \\
\hline & Tahap I & & & & \\
1 & Fakir & 300 & 4.000 & 1.200 .000 & $83,15 \%$ \\
2 & Sabilillah & 14 & 3.082 & 43.150 & $2,99 \%$ \\
3 & Ibnu sabil & 200 & 1.000 & 200.000 & $13,86 \%$ \\
& Total & 514 & & 1.443 .150 & $100 \%$ \\
& Tahap II & & & & \\
1 & Fakir & 828 & 1.125 & 932.000 & $33,89 \%$ \\
2 & Miskin & 4.180 & 317 & 1.324 & $48,15 \%$ \\
3 & Amil & 28 & 2.894 & 275.000 & $10 \%$ \\
4 & Muallaf & 18 & 3.000 & 54.000 & $1,96 \%$ \\
5 & Gharimin & 8 & 2.500 & 20.000 & $0,73 \%$ \\
6 & Fisabilillab & 72 & 1.055 & 76.000 & $2,76 \%$ \\
7 & Ibnu sabil & 66 & 1.045 .455 & 69.000 & $2,51 \%$ \\
\multicolumn{7}{c}{ Total } & 5.200 & & 2.750 .000 & $100 \%$ \\
\hline Sumber: Baitul Mal Kota Lhokseumawe
\end{tabular}

Sumber: Baitul Mal Kota Lhokseumawe

Dalam jurnal-jurnal nasional, publikasi penelitian terhadap kontribusi zakat telah dilakukan, diantaranya kontribusi zakat untuk wilayah Bogor, Jawa Tengah, Medan, Boyolali, dan penelitian yang dilakukan oleh Badan Zakat Nasional (BAZNAS) untuk mengetahui peran zakat untuk mencapai Maqashid Syariah. Penelitian yang dilaksanakan oleh BAZNAS tersebut menggunakan metode ANP sebagai pendekatan untuk membuat keputusan. Metode 
ANP digunakan untuk mengambil keputusan yang lebih kompleks.

Dalam agama Islam, tujuan kontribusi zakat searah dengan tujuan syariah atau yang disebut dengan maqashid syariah. Sehingga untuk menempatkan kontribusi zakat yang digunakan untuk mencapai tujuan yang sesuai dengan maqashid syariah, maka dapat dilihat dengan mengetahui relevansi antara kontribusi zakat dengan maqashid syariah dan prioritas dari masing-masing tujuannya. Pada Baitul Mal Kota Lhokseumawe penyaluran bantuan sosial belanja zakat pada sekretariat dikontribusikan untuk senif-senif yang telah ditetapkan, diantaranya fakir, miskin, riqab, amil, muallaf, gharimin, fisabilillah, dan ibnu sabil. Sedangkan, untuk maqashid syariah, tujuan yang akan dicapai adalah untuk memelihara agama, jiwa, intelektual, keturunan dan harta. Dari kontribusi tersebut, maka tujuan-tujuan yang sesuai dengan maqashid syariah dapat tercapai.

Penelitian tentang relevansi kontribusi zakat dengan maqashid syariah masih relatif sedikit. Oleh karena itu, penting untuk melakukan penelitian tentang relevansi kontribusi zakat dengan maqashid syariah, khususnya di Kota Lhokseumawe. Dengan demikian, maka penulis tertarik untuk mengadakan penelitian Model Penyaluran Zakat Sebagai Instrumen Keuangan Sosial Untuk Mencapai Maqashid Syariah Dengan Menggunakan Pendekatan Analytic Network Process.

\section{Tinjauan Kepustakaan}

\section{Zakat}

Zakat ditinjau dari segi bahasa (lughatan) mempunyai beberapa arti, yaitu keberkahan (albarakatu), pertumbuhan dan perkembangan (alnama), dan kesucian (al-tabaratu). Sedangkan arti zakat secara istilah (shar'iyah) merupakan bagian dari harta dengan persyaratan tertentu yang telah ditetapkan oleh Allah SWT mewajibkan kepada pemiliknya untuk diserahkan mustahiq (Nawawi dalam Muzdhalifah, 2014:13).

\section{Kontribusi Zakat}

Undang-undang Nomor 38 Tahun 1999 Tentang Pengelolaan Zakat pada Pasal 16 ayat 1 dan 2, yaitu:
1. Hasil pengumpulan zakat didayagunakan untuk mustahiq sesuai dengan ketentuan agama.

2. Pendayagunaan hasil pengumpulan zakat harus berdasarkan skala prioritas. Dengan penjelasan ayat 2 pasal tersebut adalah "Mustabiq" sesuai dengan perintah Allah SWT dalam Al-Quran.

\section{Kriteria Dalam Kontribusi Zakat}

\section{Kriteria Fakir}

Imam mazhab yang Tiga dalam Al-Qardawi (2001:513) berpendapat bahwa kriteria untuk para fakir adalah sebagai berikut:

1. Mereka yang tidak punya apa-apa.

2. Mereka yang mempunyai rumah, barang atau perabot yang tidak berlebihan.

3. Mereka yang punya harta atau usaha tapi tidak mencukupi untuk diri dan keluarganya, yaitu penghasilanya tidak memenuhi separuh atau kurang dari kebutuhan.

\section{Kriteria Miskin}

Preferensi terhadap kreteria miskin perlu dipahami dan di jelaskan. Menurut tiga imam mazhab di atas, kriteria dari miskin adalah sebagai berikut:

1. Mereka yang memiliki mata uang kurang dari nisab.

2. Mereka yang memiliki kurang dari nisab selain mata uang.

3. Mereka yang memiliki harta atau usaha yang hanya dapat mencukupi separuh atau lebih kebutuhan untuk diri dan tanggungannya.

\section{Kriteria Amil}

Preferensi kreteria amil Menurut Al-Qardawi (2001:545) menyatakan bahwa amil zakat terdiri dari beberapa kriteria, yaitu:

1. Petugas zakat itu seorang mukallaf (orang dewasa yang sehat akal dan fikirannya).

2. Petugas zakat yang jujur.

3. Petugas zakat yang memahami hukumhukum zakat.

\section{Kriteria Muallaf}

Kriteria muallaf yang dikemukakan oleh AlQardawi (2001:564) adalah sebagai berikut:

1. Golongan orang yang baru masuk dalam Agama Islam.

2. Pimpinan dan tokoh masyarakat yang telah memeluk agama Islam dan yang mempunyai 
sahabat-sahabat orang kafir.

3. Pimpinan tokoh kaum muslimin yang berpengaruh dikalangan kaumnya, akan tetapi imannya masih lemah.

\section{Kriteria Gharimin}

Menurut Al-Qardawi (2001:596) kriteria gharim adalah sebagai berikut:

1. Orang yang berhutang untuk memenuhi kehidupannya, dan tidak memiliki kemampuan baik dari segi harta atau usaha untuk membayarnya.

2. Orang yang mempunyai utang untuk melaksanakan ketaatan atau mengerjakan sesuatu urusan yang diperbolehkan.

3. Hutangnya adalah sesuatu yang bisa ditahanya, dengan kata lain hutang tersebut dapat dialihkan.

\section{Kriteria Fisabilillah}

Menurut Al-Qardawi (2001:596) kriteria gharim adalah sebagai berikut:

1. Orang yang berhutang untuk memenuhi kehidupannya, dan tidak memiliki kemampuan baik dari segi harta atau usaha untuk membayarnya.

2. Orang yang mempunyai utang untuk melaksanakan ketaatan atau mengerjakan sesuatu urusan yang diperbolehkan.

3. Hutangnya adalah sesuatu yang bisa ditahanya, dengan kata lain hutang tersebut dapat dialihkan.

\section{Kriteria Ibnu sabil}

Menurut Al-Qardawi (2001:662) Kriteria dari Ibnu sabil adalah sebagai berikut:

1. Orang yang diusir dan minta suaka.

2. Orang yang mempunyai harta, akan tetapi tidak mampu mendapatkan, walaupun di negerinya.

3. Musafir demi kemaslahatan.

\section{Maqashid Syariah}

Menurut Anwar (2018:284) yang menyatakan bahwa, "Secara bahasa, maqashid syariah terdiri dari dua kata, yakni maqasid dan syariah. Maqashid adalah bentuk jamak dari maqashid yang berarti kesengajaan atau tujuan, syariah berarti jalan menuju sumber air. Jalan menuju sumber pokok kehidupan". Pada lima tujuan syariah, dalam Divisi Riset dan Kajian BAZNAS (2017:11) atas pernyataan al-Ghazali, yaitu:
"Dan tujuan pemberlakuan syariah atas hamba adalah untuk memelihara agama (bifz al-din), memelihara jiwa (bifz, al-nafs), memelihara akal (bifz al-'aq), memelihara keturunan (bifz al-mal), dan memelihara hartanya (bifz al-mal). Setiap sesuatu yang dapat menjaga kelima hal tersebut adalah maslahah dan sebaliknya, segala sesuatu yang meninggalkan kelima hal tersebut adalah mafsadah".

\section{Metodologi Penelitian}

\section{Populasi dan Penentuan Sampel}

Populasi dalam penelitian ini adalah para pakar dan praktisi yang memahami tentang zakat. Pengambilan sampel dilakukan dengan metode purposive sampling, yaitu cara menentukan sampel penelitian mengunakan beberapa pertimbangan tertentu yang bertujuan agar data yang diperoleh nantinya bisa lebih representatif (Sugiyono 2016). Berdasarkan kriteria-kriteria dan pertimbangan, sampel dalam penelitian ini sebanyak 7 pakar dan praktisi yang memahami tentang zakat.

\section{Metode Analisis Data}

Penelitian ini merupakan penelitian analisis kualitatif yang bertujuan untuk menangkap suatu nilai atau pandangan yang diwakili para pakar dan praktisi syariah tentang relevansi kontribusi zakat untuk mencapai maqashd syariah. Alat analisis yang digunakan adalah metode ANP dan diolah dengan menggunakan Software Super Decision.

Landasan ANP menurut Saaty dalam Rusydiana dan Abrista (2013:14), mengungkapkan bahwa ANP memiliki empat aksioma yang menjadi landasan teori, antara lain:

1. Respirokal, aksioma ini menyatakan bahwa jika PC (EA,EB) adalah nilai pembandingan pasangan dari elemen $\mathrm{A}$ dan $\mathrm{B}$, dilihat dari elemen induknya $\mathrm{C}$, yang menunjukkan berapa pasangan elemen A memiliki apa yang dimiliki elemen $B$, maka PC (EB/EA) $=1 / \operatorname{Pc}(\mathrm{EA}, \mathrm{EB})$. Misalkan, jika A lima kali lebih besar dari $\mathrm{B}$, maka $\mathrm{B}$ besarnya $1 / 5$ dari besar A.

2. Homogenitas, merupakan elemen yang dibandingkan dalam struktur kerangka ANP sebaiknya tidak memiliki perbedaan terlalu besar, yang dapat menyebabkan lebih besarnya kesalahan dalam menentukan 
penilaian elemen pendukung yang mempengaruhi keputusan.

Tabel 3. Skala Penilaian Elemen Penilaian dan Skala Numerik

\begin{tabular}{lc}
\hline \multicolumn{1}{c}{ Definition } & $\begin{array}{c}\text { Intensity of } \\
\text { Importance }\end{array}$ \\
\hline Equal Importance & 1 \\
Weak & 2 \\
Moderate Importance & 3 \\
Moderate Plus & 4 \\
Strong Importance & 5 \\
Strong Plus & 6 \\
Very strong or demonstrated importance & 7 \\
Very, very strong & 8 \\
Extreme importance & 9 \\
Sumber: Saaty dalam Rusydiana dan Abrista (2013:14) &
\end{tabular}

3. Prioritas, yaitu pembobotan secara absolut dengan menggunakan skala interval [0.1] dan sebagai dominasi relatif.

4. Dependence condition, diasumsikan bahwa susunan dapat dikomposisikan ke dalam komponen-komponen yang membentuk bagian berupa cluster.

Tahapan pada ANP terdiri dari empat tahap yaitu:

1. Tahap konstruksi model

Kontruksi model ANP disusun berdasarkan literature review secara teori maupun empiris dan memberikan pertanyaan dalam bentuk kuisioner pada pakar dan praktisi Baitul Mal Kota Lhokseumawe untuk mengkaji informasi secara lebih dalam untuk memperoleh permasalahan yang sebenarnya.

2. Kuantifikasi model

Tahap kuantifikasi model menggunakan pertanyaan dalam kuisioner ANP berupa pairwaise comparison (pembandingan pasangan) antar elemen dalam cluster dengan tujuan mengetahui pengaruh yang lebih dominan dan seberapa besar perbedaanya melalui skala numerik 1-9. Data hasil penilaian kemudian dikumpulkan dan diinput melalui software Super Decisions untuk menghasilkan output yang berbentuk prioritas dan supermatriks. Hasil dari setiap responden akan diinput pada jaringan ANP tersendiri (Ascarya dalam Rusydiana dan Abrista, 2013:42).

3. Membentuk supermatix

Supermatriks terdiri dari sub-sub matriks yang disusun dari suatu set hubungan antara dua level yang terdapat dalam model. Terdapat tiga tahap supermatriks pada model ANP, yaitu:

a. Unweighted supermatrix

Supermatrix ini berisi eigenvector yang dihasilkan dari keseluruhan matriks perbandingan berpasangan dalam jaringan. Setiap kolom dalam unweighted supermatix berisi eigenvector yang berjumlah satu pada setiap clusternya.

b. Weighted supermatrix

Supermatriks ini diperoleh dengan mengalikan seluruh eigenvector dalam unweighted supermatrix. Dengan bobot clusternya masing-masing berjumlah satu setiap satu kriteria.

c. Limit matrix

Limit matrix adalah supermatriks yang berisi bobot prioritas global dalam weighted supermatrix yang telah konvergen dan stabil. Nilai ini diperoleh dengan memangkatkan weighted supermatrix dengan $2 \mathrm{k}+1$, dimana $\mathrm{k}$ adalah satu bilangan yang besar.

4. Analisis

Menurut Ascarya dalam Ekawati (2018:154) "Uji perhitunagan sintesis dalam perhitungan metode ANP adalah meliputi Geometric Mean, dan Rater of Agreement."

a. Geometric Mean

Geometric Mean (GM) digunakan untuk mengetahui hasil penelitian individu dari para responden dan menentukan hasil pendapat pada satu kelompok. (Saaty dalam Rusyidiana dan Abrista, 2013:42). Pertanyaan berupa perbandingan pairwise comparison dari responden akan dikombinasikan sehingga membentuk konsensus. Rumus Geomtric mean adalah sebagai berikut:

$\mathrm{GM}=(\mathrm{R} 1 \times \mathrm{R} 2 \times \ldots \times \mathrm{Rn}) 1 / \mathrm{n}$

Dimana:

$\mathrm{GM}=$ Geometric Mean

$\mathrm{n} \quad=$ Jumlah Responden

$\mathrm{R}=$ Nilai Kuisioner Responden

b. Rater of Agreement

Rater of Agreement adalah ukuran yang 
menunjukkan tingkat kesesuaian (persetujuan) para responden (R1-Rn) terhadap suatu masalah dalam satu cluster. Adapun alat yang digunakan untuk mengukur rater agreement adalah Kendall's Coefficient of Concordance (W; $0<$ $\mathrm{W} \leq 1)$. W=1 menunjukkan kesesuaian yang sempurna (Ascarya dalam Rusyidiana dan Abrista, 2013:42).

Menurut Saaty dalam Rusydiana dan Abrista (2013:14), mengungkapkan bahwa ANP memiliki empat aksioma yang menjadi landasan teori, antara lain:

1. Respirokal, aksioma ini menyatakan bahwa jika PC (EA,EB) adalah nilai pembandingan pasangan dari elemen $A$ dan $B$, dilihat dari elemen induknya $C$, yang menunjukkan berapa pasangan elemen $A$ memiliki apa yang dimiliki elemen $\mathrm{B}$, maka $\mathrm{PC}(\mathrm{EB} / \mathrm{EA})=1 / \mathrm{Pc}(\mathrm{EA}, \mathrm{EB})$. Misalkan, jika A lima kali lebih besar dari B, maka B besarnya $1 / 5$ dari besar $A$.

2. Homogenitas, menyatakan bahwa elemenelemen yang dibandingkan dalam struktur kerangka ANP sebaiknya tidak memiliki perbedaan terlalu besar, yang dapat menyebabkan lebih besarnya kesalahan dalam menentukan penilaian elemen pendukung yang mempengaruhi keputusan.

3. Prioritas, yaitu pembobotan secara absolut dengan menggunakan skala interval [0.1] dan sebagai dominasi relatif.

4. Dependence condition, diasumsikan bahwa susunan dapat dikomposisikan ke dalam komponen-komponen yang membentuk bagian berupa cluster.

Tahapan pada metode ANP dapat dilihat pada gambar 3.1 berikut ini:

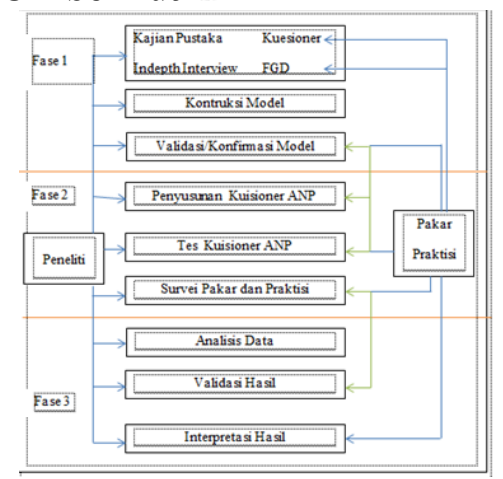

Sumber: Ascarya dalam Rusydiana dan Abrista (2013:41)

Gambar 1. Tahapan Pada Metode ANP

\section{Hasil dan Pembahasan}

\section{Dekomposisi}

Pada tahap ini, dipilih tujuh (7) responden pakar sesuai dengan kualifikasi yang dibutuhkan dalam penelitian ini. Responden pertama dalam penelitian ini adalah Wakil Ketua Majelis Permusyaratan Ulama Kota Lhokseumawe. Responden ke dua dalam penelitian ini adalah anggota Majelis Permusyawaratan Ulama Kota Lhokseumawe. Responden ke tiga dalam penelitian ini adalah teknisi kontribusi zakat Baitul Mal Kota Lhokseumawe. Responden ke empat dalam penelitian ini adalah Ketua Skretariat Baitul Mal Kota Lhokseumawe. Responden ke lima dalam penelitian adalah Ketua Program Studi Akuntansi Lembaga Keuangan Syariah Kota Lhokseumawe. Responden ke enam dalam penelitian ini adalah Wakil Ketua Majelis Permusyawaratan Ulama Kabupaten Aceh Utara. Responden ke tujuh (terakhir) dalam penelitian ini adalah Teknisi Baitul Mal Universitas Malikussaleh Lhokseumawe. Adanya ketidaksesuaian jadwal dari para pakar, maka dalam penelitian ini melakukan Indepth Interview (wawancara). Pada wawancara tersebut para pakar dan tekhnisi mengisi kuesioner yang telah dibuat. Pengisian kuesioner ini di perlukan untuk pengukuran dengan menggunakan skala rasio.

\section{Jaringan ANP}

Gambaran model ANP dalam Super Decisions yang di maksud dalam studi ini adalah sebagaimana terlihat pada gambar berikut ini:

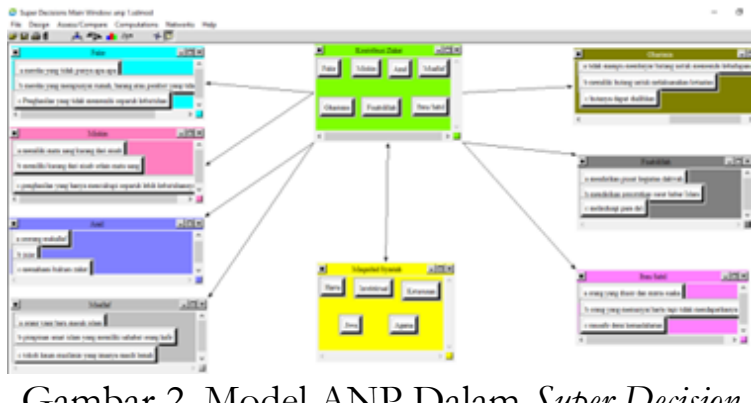

Gambar 2. Model ANP Dalam Super Decision

\section{Pairwise Comparison \\ Prioritas Kriteria Kontribusi Zakat}

Hasil dari pairwise comparison merupakan prioritas dari setiap pertanyaan yang terdapat dalam kuesioner. Hasil perhitungan yang muncul dari setiap pertanyaan merupakan bobot 
prioritas dengan nilai tertentu yang digunakan untuk menentukan prioritas dari setiap pertanyaan. Hasil perhitungan dari prioritas kriteria senif kontribusi zakat adalah sebagai berikut:

Tabel 4. Hasil Perhitungan Rata-Rata Prioritas Kriteria Senif Kontribusi Zakat.

\begin{tabular}{lc}
\hline \multicolumn{1}{c}{ Asnaf } & Rata-rata \\
\hline Fakir & 0.32944 \\
\hline Miskin & 0.33333 \\
\hline Amil & 0.33333 \\
\hline Muallaf & 0.33333 \\
\hline Gharimin & 0.33333 \\
\hline Fisabilillah & 0.33333 \\
\hline Ibnu sabil & 0.33333 \\
\hline
\end{tabular}

Sumber : Data diolah 2020

\section{Prioritas Maqashid Syariah Pada Senif Kontribusi Zakat}

Hasil perhitungan kontribusi zakat pada senif kontribusi zakat dapat dilihat pada Tabel 5 berikut ini:

Tabel 5. Hasil Perhitungan Prioritas Maqashid Syariah Pada Senif Kintribusi Zakat.

\begin{tabular}{lccccc}
\hline & Agama & Harta & Intelektual & Jiwa & Keturunan \\
\hline Fakir & 0.36748 & 0.19361 & 0.13588 & 0.16637 & 0.13665 \\
\hline Miskin & 0.53171 & 0.01460 & 0.17191 & 0.22773 & 0.05406 \\
\hline Amil & 0.53887 & 0.10720 & 0.12834 & 0.16631 & 0.05928 \\
\hline Muallaf & 0.56818 & 0.13322 & 0.11687 & 0.11357 & 0.06818 \\
\hline Gharim & 0.07902 & 0.57119 & 0.07098 & 0.25364 & 0.02516 \\
\hline Sabilillah & 0.53366 & 0.15038 & 0.10554 & 0.16089 & 0.04953 \\
\hline Ibnu sabil & 0.51682 & 0.16835 & 0.10222 & 0.13353 & 0.07908 \\
\hline
\end{tabular}

Sumber: Data diolah 2020

Dari tabel di atas dapat diketahui bahwa jika dilihat dari senif kontribusi zakat maka maqashid syariah yang tercapai dapat diketahui dari hasil bobot prioritas tertinggi ditunjukkan oleh maqashid syariah untuk menjaga agama dengan rata-rata bobot prioritas sebesar 0.44796 . Bobot prioritas yang kedua adalah untuk menjaga harta dengan rata-rata bobot prioritas sebesar 0.19122. Bobot prioritas yang ketiga adalah untuk menjaga jiwa dengan rata-rata bobot prioritas sebesar 0.1758. Bobot prioritas yang keempat adalah untuk menjaga Intelektual. Bobot Prioritas yang ke empat adalah untuk menjaga intelektual dengan rata-rata bobot prioritas sebesar 0.11882 . Bobot prioritas yang kelima adalah untuk menjaga keturunan.

\section{Prioritas Kontribusi Zakat Untuk Mencapai Maqashid Syariah}

Hasil perhitungan prioritas kontribusi zakat untuk mencapai maqashid syariah dapat dilihat pada Tabel 6 berikut ini:

Tabel 6. Hasil Perhitungan Kontribusi Zakat Untuk Mencapai Maqashid Syariah.

\begin{tabular}{lccccccc}
\hline & Fakir & Miskin & Amil & Muallaf & Gharim & Sabilillah & Ibnu Sabil \\
\hline Agama & 0.38377 & 0.11327 & 0.03490 & 0.08372 & 0.06010 & 0.25549 & 0.06875 \\
\hline Harta & 0.38032 & 0.16877 & 0.03482 & 0.23653 & 0.04984 & 0.05433 & 0.07538 \\
\hline Intelektual & 0.36175 & 0.18159 & 0.12135 & 0.07134 & 0.09328 & 0.10332 & 0.06827 \\
\hline iwwa & 0.43792 & 0.19633 & 0.04592 & 0.07955 & 0.08403 & 0.08804 & 0.06822 \\
\hline Keturunan & 0.43384 & 0.11580 & 0.10090 & 0.12551 & 0.07425 & 0.10352 & 0.04619 \\
\hline
\end{tabular}

Sumber : Data diolah 2020

Berdasarkan dari perhitungan diatas dan rata-rata dari perhitungan tersebut, maka dapat diketahui bahwa jika dilihat dari tujuan untuk mencapai tujuan dari maqashid syariab maka kontribusi zakat secara berurutan diberikan kepada senif fakir dengan rata-rata bobot prioritas sebesar 0.28537. Miskin dengan rata-rata bobot prioritas sebesar 0.11082. Sabilillah dengan rata-rata bobot prioritas sebesar 0.08524. Muallaf dengan ratarata bobot prioritas sebasar 0.08524. Gharim dengan rata-rata bobot prioritas sebesar 0.05164. Amil dengan rata-rata bobot prioritas sebesar 0.04827. Ibnu sabil dengan rata-rata bobot prioritas sebesar 0.04669 .

\section{Kesimpulan}

1. Prioritas dari kriteria masing-masing senif kontribusi zakat. Kriteria dengan prioritas tertinggi untuk senif fakir adalah mereka yang tidak memiliki apa-apa. Kriteria dengan prioritas tertinggi untuk senif miskin adalah mereka yang memiliki mata uang kurang dari nisab. Kriteria dengan prioritas tertinggi untuk senif amil adalah petugas zakat itu seorang mukallaf. Kriteria dengan prioritas tertinggi untuk senif muallaf adalah golongan orang yang baru masuk dalam agama Islam. Kriteria dengan prioritas tertinggi untuk senif gharimin adalah orang yang berhutang untuk memenuhi kehidupanya. Kriteria dengan prioritas tertinggi untuk senif fisabilillah adalah mendirikan pusat kegiatan bagi kepentingan dakwah. Kriteria dengan prioritas tertinggi untuk senifibnu sabil adalah musafir demi kemaslahatan.

2. Prioritas maqhasid syariah pada senif 
kontribusi zakat adalah untuk menjaga agama.

3. Prioritas kontribusi zakat untuk mencapai maqashid syariah yang paling utama adalah diberikan kepada senif fakir.

Berdasarkan hasil pengujian tersebut, penulis merekomendasikan untuk melakukan uji validasi/konfirmasi model ANP, menambah teori mengenai ulama klasik dan ulama kontemporer, serta menambah responden dari para pakar dan praktisi non pemerintahan.

\section{Daftar Pustaka}

Al-Qardawi, Y. (2001). Hukum Zakat: Studi Komparatif Mengenai Status dan Filsafat Zakat Berdasarkan Qur'an dan Hadis, PT Pustaka Litera Antar Nusa, Bogor.

Anwar. (2017). Analisis Kinerja Menggunakan Metode Balanced Scorecard (Study Kasus Baitul Mal Kota Lhokseumawe). Seminar Nasional Teknik Industri. ISSN 23387122, 13-14 September 2017. Hal. 252263.

Anwar, S. et.al. (2018). Pengantar Falsafah Ekonomi dan Keuangan Syariah. Edisi I, Cetakan I, PT Raja Grafindo Persada, Depok.

Afifi. et.al. (2010). Kekuatan Zakat "Hidup Berkah Rezeki Melimpah”. Cetakan I, Pustaka Albana (Anggota Ikapi), Yogyakarta.

Aristoni. et.al. (2015). Reformulasi Harta Sebagai Sumber Zakat Dalam Perspektif Ulama Kontemporer. Jurnal ZISWAF, Vol.2, No.2, Desember 2015. Hal. 296316.

Asoaiasi Dosen Ekonomi Syariah, FORDEBI. (2017). Ekonomi Dan Bisinis Islam. Edisi I. Cetakan 2, PT Raja Grafindo Persada, Depok.
Canggih. et.al. (2017). Inklusi Pembayaran Zakat di Indonesia. Jurnal Ekonomi dan Bisnis Islam. Vol.3, No.1, Januari-Juni 2017. Hal. 1-11.

Departemen Agama RI. (2015). Al-Qur'an Tajwid dan Terjemahan. Cetakan ke 10, CV Penerbit Diponegoro, Bandung.

Ekawati, R. et.al. (2018). Penilaian Performa Supllier Menggunakan Pendekatan Analytic Network Process. Journal Industrial Servicess, Vol.3, No.2, 2 Maret 2018.

Hadi, K. (2012). Implementasi Maqoshid Syariah Sebagai Indikator Perusahaan Islami. Jurnal AL-AZHAR Indonesia Seri Pranata Sosial, Vol.1, No.3, Maret 2012. Hal.140-150.

Haryanto, S. (2016). Accounting For Zakat On Income Critical Study Based On Government Regulation (Case Study In Aceh Province Of Indonesia). International Journal of Business, Accounting and Management, Vol.1, 03 Desember 2016. Hal.47-52.

Katsir, I. (2013). Fikih Hadits Bukhari Muslim. Cetakan I, Ummul Qura, Jakarta.

Mustarin, B. (2017). Urgensi Pengelolaan Zakat Terhadap Peningkatan Perekonomian Masyarakat. Jurisprudentie. Vol.4, No.2, Desember 2017. Hal. 83-95.

Muzlifah, E. (2013). Maqoshid Syariah Sebagai Paradigma Dasar Ekonomi Islam. Jurnal Ekonomi dan Hukum Islam, Vol.3, No.2. Hal. 73-93.

Muzdalifah, M. (2014). Pengaruh Strategi Pengumpulan Dana Zakat (Below The Line Dan Above The Line) Terhadap Peningkatan Perolehan Dana Zakat Pada Lembaga Yayasan Dana Sosial Al-Falah Surabaya. Undergraduate thesis, UIN Sunan Ampel Surabaya. 
Nawawi, I. (2013). Manajemen Wakaf Dan Zakat. VIV Pres: Jakarta.

Nuruddin, M. (2014). Transformasi Hadishadis Zakat Dalam Mewujudkan Ketangguhan Ekonomi Pada Era Modern. Jurnal ZISWAF, Vol.1, No.2, Desember 2014.Hal. 293-314.

Nanggroe Aceh Darussalam. (2008). Qanun Aceh Nomor.10 Tahun 2007 Tentang Baitul Maal. Sekretaris Daerah Aceh, Nanggroe Aceh Darussalam, Banda Aceh.

Pusat Kajian Strategis BAZNAS. (2017). Peran Zakat Dalam Sustainable Development Goals Untuk Pencapaian Maqashid Syariah. Cetakan I, Pusat Kajian Strategis Badan Amil Zakat Nasional, Jakarta.

Republik Indonesia, (1999). Undang-undang Nomor.38 Tahun 1999 Tentang Pengelolaan Zakat. Sekretaris Negara Repulik Indonesia, Jakarta
Republik Indonesia, (2011). Undang-undang Nomor.23 Tahun 2011 Tentang Pengelolaan Zakat. Menteri Hukum dan Hak Asasi Manusia, Jakarta.

Rusydiana, A., dan Abrista Devi. (2013). Analytic Network Process: Pengantar Teori dan Aplikasi. Cetakan Pertama, SMART Publishing, Bogor.

Sugiyono. (2016). Metode Penelitian Kuantitatif, Kualitatif dan R\&D. PT Alfabet, Bandung.

Suryani, Hendryadi. (2015). Metode Riset Kuantitaif: Teori Dan Aplikasi Pada Penelitian Bidang Manajemen dan Ekonomi Islam. Edisi Pertama, Prenadamedia Group, Jakarta.

Syahrir, S. (2017). Pemahaman Masyarakat Terhadap Kewajiban Zakat Di Kecamatan Maritengngae Kabupaten Sindereng Rappang. Skripsi. Fakultas Syariah dan Hukum, UIN Alauddin Makassar. 